\title{
The Portrait of Matteo Ricci
}

\section{A Mirror of Western Religious and Chinese Literati Portrait Painting}

\author{
César Guillen-Nuñez \\ Macau Ricci Institute \\ cguillen@riccimac.org
}

\begin{abstract}
This article discusses a rather unusual portrait that depicts the Italian missionary Matteo Ricci (1552-1610), to be found today in the Gesù church in Rome. When it was first exhibited it aroused such excitement among Jesuits that it was displayed next to the portraits of St. Ignatius of Loyola and St. Francis Xavier. At an uncertain date, a small inscription was attached to the frame with Ricci's name, his years of birth and death, and a statement that the painting had been exhibited in the vestibule of the Gesù residence in 1617 , but that its artist was unknown. Although the painter's name was disclosed as that of the Chinese-Macanese Jesuit brother You Wenhui (alias Manuel Pereira) in an account by Sabatino de Ursis soon after Ricci's death, both the painter and his work have remained practically ignored by most researchers. This article studies the portrait and its creator from an art-historical perspective in much greater detail than previously. Stylistic and iconographic influences of Chinese Ming portraiture observable in the style of the work are identified, as are features from late sixteenth-century Counter-Reformation portraits. Certain aspects of Ricci's contributions to Chinese science are also discussed, along with a number of contemporary theological arguments that tell us much about the nature of the portrait, its subject, its creator, and its deep spiritual significance.
\end{abstract}

\section{Keywords}

Matteo Ricci portrait - You Wenhui (Manuel Pereira) - Ming portraiture - El Greco Cosmography - art-historical appraisal

This article looks at the only known authentic likeness of the Italian Jesuit missionary Matteo Ricci. It was created for posterity by a little-known Chinese 
artist in late Ming China. ${ }^{1}$ An anonymous and undated work, the portrait is thought to have been painted after May 11, 1610, the date of the famous missionary's death, and certainly by the end of 1612, as we shall see below. Although it was done from memory, as was customary in ancestral portraits in East Asian countries including China, it was created when the face of Ricci was still fresh in the mind of the painter. While fairly well known to specialists of Matteo Ricci and of the Jesuits' China mission, very little has been written about it by historians of art. $^{2}$

The most reliable missionary accounts of the portrait's subject are those by Ricci himself, who personally disliked having his portrait painted. The only other Ricci image reported to have been painted is a 1601 full-length likeness done by eunuch artists at the imperial court of the Wanli emperor, but Ricci's companion, the Spaniard Diego Pantoja, also portrayed by them, objects that in these paintings neither of them were recognizable. ${ }^{3}$ If only as a true record of Ricci's face, therefore, this is a work that merits the attention of scholars. In the following pages, the portrait is studied as a work of art in its own right, as are details of the life of the painter and his subject gathered from contemporary sources. A number of stylistic and iconographic currents of Chinese portraiture of the period are identified, as are relevant features that derive from late sixteenth-century Counter-Reformation portraiture in Europe. Certain aspects of Ricci's contribution to Chinese science are also discussed, as they shed light both on the personality of the missionary and on the prestige he had attained, if not with the mandarinate as a whole, certainly within a select circle of Chinese literati. Indeed Ricci was to write that in the Middle Kingdom he was considered the greatest mathematician on earth, as we shall see below. Finally, the last section of this article considers a number of theological points because they tell us much about the nature of the portrait, its creator, and its spiritual significance. Indeed, it is the integration of these artistic and theological influences which makes the portrait practically unique as an expression of Roman Catholic religious portraiture of the early Counter-Reformation period.

1 This is an expanded and more elaborate version of a paper presented at the International Conference Misjonarze między Wschodem i Zachodem w 400 rocznicę śmierci Ojca Matteo Ricciego SJ, Poznań University, Poland, May 10-11, 2010, as well as of a shorter study published in Portrait of a Jesuit: Matteo Ricci (Macau Ricci Institute: Macau, 2010), 83-100.

2 Two leading if limited discussions on the subject can be found in John E. McCall, "Early Jesuit Art in the Far East IV: In China and Macao before 1635," Artibus Asiae 11, no. 1-2 (1948): 50-51; G.A. Bailey, Art on the Jesuit Missions in Asia and Latin America 1542-1773 (Toronto: University of Toronto Press, 2001), 72.

3 Fonti Ricciane (Rome: La Libreria dello Stato, 1942-49), 3 vols. [hereafter FR], II, 597, 129n3; $130 n 3$. 


\section{The Portrait}

The painting in question here is one of the most remarkable to have emerged from the Jesuits' China mission, a work difficult to classify art historically because of its hybrid nature.

It is an oil painting on canvas, showing the Italian Jesuit missionary Matteo Ricci 利瑪竇 $\left(155^{2-1610}\right)$ as an elderly man, famous as a missionary, a scientist, and a man with a prodigious memory (fig. 1$).{ }^{4}$ The viewer is presented with a three-quarter-length portrait, with Ricci wearing a black hat and a silken thick black robe with a white collar and his hands concealed under the wide sleeves in the manner of Chinese literati. Ricci is imagined by the artist as standing against a dusky blue-grey sky streaked with faint white horizontal stripes, which intensify in brightness over blue rolling hills just visible in the background. His body is shown in a frontal position with only the head slightly turned towards the right in three-quarter profile. The painter evidently found modeling a figure in three dimensions difficult, although he liked symmetrical shapes, as seen in the treatment of the sleeves' shadows, the shapes of the silk's sheen, and the chin beard.

In the painting Ricci's features reveal a venerable man with an aquiline nose and furrowed forehead and face-an indication of the hardships endured in the China mission. As early as his 4os, Ricci himself had begun to lament the fact that he was aging fast; others also noticed his prematurely white hair. ${ }^{5}$ But here Ricci's weathered face has been artistically mellowed, with stylized wrinkles and a well-groomed, flowing, greyish-white beard with sideburns. A thin mustache frames his face and mouth, while his chin beard falls over his neck with three symmetrical curls in the middle. Unlike the indistinct long ribbons that fall behind his ears and over his shoulders, the hard-edge effect of the Ming scholar's headgear covering part of Ricci's forehead and whitening hair is quite striking. ${ }^{6}$ But of all the forms and facial features, it is the eyes and their gaze that catch the viewer's attention.

Ricci's curious headgear, which has replaced the black biretta of Catholic priests, is similar to the one seen in the print published in Athanasius Kircher's China illustrata (1667), where Ricci's black habit has been embellished to appear more fashionable. In this well-known print there is a quite fanciful depiction of Ricci in lively dialogue with his close friend, the Chinese scholar

\footnotetext{
4 Jonathan D. Spence, The Memory Palace of Matteo Ricci (London: Faber and Faber, 1985).

$5 \quad F R$, II, $569 n_{5}$.

6 See the headgear worn by the Ming Confucian philosopher Wang Yangming, Harvard Art Museums. <http://www.harvardartmuseums.org/art/202380 > (accessed on 08. 13. 2013).
} 




FIGURE 1 Fr. Matteo Ricci of Macerata YouWenhui 游文輝, alias Manuel Pereira c. 1610, oil on canvas, $120 \times 95 \mathrm{~cm}$. (C) Society of Jesus, Il Gesù, Rome.

convert Xu Guangqi 徐光啟 (1562-1633). In the portrait, therefore, Ricci is shown in the way that he had reinvented himself in 1595, following the admonition of Alessandro Valignano, Father Visitor to the Asian missions, that Jesuit missionaries in China should grow a beard, wear their hair long, and dress in silk in the manner of Chinese literati to avoid being mistaken for Buddhist monks. The latter descended from poor people of low birth and were held in 
low esteem in China, something it was felt that the Jesuits should avoid at all costs. They were instead to be, and to be regarded as, predicatori literati [scholar-preachers]. In reality, the missionaries were adopting and adapting the formal robes prevailing among Chinese scholars since at least the Song dynasty. ${ }^{7}$

The emblem of the Society of Jesus appears within an orb to Ricci's right, in the spot where one would normally expect an armorial insignia in a sixteenthcentury portrait, whenever the latter was included. Here the emblem also resembles a setting sun in a landscape at dusk. But the way in which the emblem is used indicates, along with other details, that this portrait is not to be understood as a strictly realistic representation. It is rather one in which the missionary, while physically resembling Ricci, is seen as if in a twilight vision that transfigures him.

A commemorative inscription in Latin, set in a narrow light band at the bottom of the painting, announces the sitter's identity to posterity, "P. Mattheus Riccius Maceratensis Qui Primus E Societate Jesu Evangelium in Sinas Invexit Obiit Anno Salutis 1610. Aetatis 6o." This form of inscription is quite typical of contemporary portraiture in the West, including late sixteenth- and early seventeenth-century engravings. It gives full credit to the great missionary, recording the fact that he was the first Jesuit who introduced the Gospel to China. The last part of the inscription states that he died in 1610, when he was sixty years old, but this could have been either an error or, following Chinese tradition, an intentional addition of three years. The latter prescribed that one year be added to the year of the death of a sage, to denote earth below, earth above, and heaven. ${ }^{8}$ This distinguishing characteristic suggests that the inscription was drafted by Chinese converts and the Jesuits in China. The tracing of the inscription's capitals betrays an imperfect proficiency in their spacing and other features, as in the words evangelium and invexit, and this may indicate that they were inscribed by the painter. Matteo Ricci, who had died on May 11 of the year mentioned there, was actually born in Macerata, Italy, on October $6,155^{2}$. He was therefore fifty-seven years and seven months at the time of his passing. He had served almost twenty-eight years in the China mission. ${ }^{9}$

7 FR, I, 125-126, 336-338, 358; China and Maritime Europe 1500-18oo:Trade, Settlement, Diplomacy and Missions, ed. John E. Wills, Jr. (Cambridge: Cambridge University Press, 2011), 88-9.

8 I am most grateful to Fr. Gianni Criveller, who shared with me his own research on this unusual tradition, which to date gives the most likely explanation for the year of death in the portrait.

$9 \quad F R$, II, $542 \mathrm{n} 2$. 


\section{The Painter}

Who exactly was this forgotten painter? Although comparatively little is known about him there are a few contemporary records that disclose his identity. As is already well known to specialists, a manuscript journal left behind by Ricci was edited and translated into Latin in 1614 by the French Jesuit Nicolas Trigault (1577-1628). Here we find one of the two main sources that refer to Ricci's portrait and its painter. $^{10}$ Trigault's Latin version recounts how among those accompanying Ricci at the time of his death in Beijing on May 11, 1610 there were several of his confrères, including a lay brother who, because he had a fair knowledge of painting, was repeatedly beset by Jesuit neophytes with requests, "a fare il ritratto del Padre per comune consolazione" [to make a portrait of the Father for the consolation of all]. ${ }^{11}$ Although this statement allows us to give an approximate date for the execution of the painting, it says little of its painter. Pasquale M. D'Elia, the editor of Ricci's manuscript, published in Rome over 300 years later as the Fonti Ricciane, reproaches Trigault for his habit of omitting the names of painters, which in this case includes the lay brother who created the remarkable posthumous portrait of Matteo Ricci. ${ }^{12}$

This anonymous Chinese painter was You Wenhui 游文輝, or to give him his Portuguese name, Manuel Pereira. His name was fortunately rescued from oblivion by Ricci's fellow Italian, Sabatino de Ursis, also a Jesuit. In this second account on how the portrait of Ricci came to be painted, de Ursis states that those Christians present at Ricci's last moments held him to be the apostle of the China mission and a saint, and that the principal ones among them "got on their knees, imploring Brother Manuel Pereira to make a true likeness of the said Father." 13

In spite of De Ursis's more precise description of the event, Ricci's papers and the fate of the portrait were destined to be controversially linked to Nicolas Trigault, mainly because of the whereabouts of the portrait after it was

10 Ricci's original manuscript in ARSI, Jap.Sin. 106a. See Della entrata della Compagnia di Giesù e Christianità nella Cina, ed. P. Corradini, preface F. Mignini (Quodlibet: Macerata, 200o), in particular xli-lii, containing an extensive Ricci bibliography, and lv-lvii, on the ARSI location of the Ricci papers. A biographical entry on Trigault by G. Dunne can be found in $\mathrm{DHCJ} 4: 3838-3839$.

11 FR, II, 543. De christiana expeditione apud Sinas suscepta ab Societate Jesu, ex P. Matthaei Riccii, 5, ed. and trans. Nicolas Trigault (Joannis Jullieron typographer: Lyons, 1616), 598. All English translations are my own.

$12 \quad F R$, II, 543, 543n3.

13 Sabatino de Ursis, S.J., P. Matheus Ricci S.J., Relação (Macao: Missão Portuguesa de Macau Commemorative Publication, 1910), 58. On Ricci's last days, see FR, II, 536-43 [958-64]. 
completed. During his voyage to Rome via Macao from early 1613 , Trigault is known to have taken Ricci's papers and it is very likely that the portrait was included among his belongings. Trigault arrived in Rome at the end of 1614 and the portrait was later delivered to the Gesù, the main church and residence of the Society of Jesus in Rome, where it was exhibited in 1617 and where it is still to be found today. ${ }^{14}$

As for its painter and his painting, only fragmentary details may be gathered from the available sources. From the Society of Jesus' Roman archives it may be gathered that You Wenhui received the name of Manoel (sic) Pereira when he was baptized a Christian. ${ }^{15}$ The scant information scattered in the latter source is quite valuable because Ricci himself provided at least a few facts. As mentioned, subsequent to Ricci's death, Nicolas Trigault added several colorful chapters to Ricci's manuscript and filled in a few gaps relating to Pereira's activity.

Some of the most valuable information regarding the artist is found in the catalogues of houses and residences of the Society in its vice-province of China and Japan, today in the Jesuit archives in Rome. The one from 1603 lists You Wenhui by his Portuguese name Manoel Pereira, and calls him an irmão [lay brother], residing in the Jesuit residence of the Cidade Real de Nanquim [Royal City of Nanjing]. But D'Elia has contested this date, arguing that he was only admitted to the Society at the end of 1603 and became a brother on August 15, ${ }_{1605}{ }^{16}$ Like his other Chinese confrère, Zhong Mingren 鍾鳴仁 (baptized Sebastiano Fernandez, 1562-1621), in the 1603 catalogue his nationality is given as China de Macao [Macao Chinese]. In the Fonti Ricciane, the first time he is significantly mentioned in connection with Matteo Ricci is as a member of a small group of confrères accompanying Ricci and Lazzaro Cattaneo in a hired boat, travelling from the city of Nanchang in Jiangxi to Nanjing. This occurred on the day after the feast of the birth of St. John the Baptist, that is, on June 25, $1598 .{ }^{17}$ The boat trip to Nanjing, made under the protection of an influential

\footnotetext{
$14 \quad F R$, II, 9-10n7; 543n3.

15 ARSI, Jap.Sin. 25, f. 66r; ARSI, Jap.Sin. 134, ff. 300 ${ }^{\mathrm{r}}$, 301v, 303, 304, 306, 308; ARSI, Jap.Sin. 135, ff. $4-5$. These entries include the 1621 to 1628 catalogs listing members of the Society, where Pereira is mentioned. See also: FR, II, 9n7. In these catalogs his name sometimes appears in Latin as Emmanuel or Emanuel Pereirus. In the $F R$ his Chinese name is also spelt Yu Wen-hui or, more oddly, “Ieuuenhoei.” Manuel, to be used throughout this text, is a modern spelling. He should not be confused with his namesake and near contemporary, the great Portuguese sculptor Manuel Pereira (1588-1683), who was active in Spain.

16 ARSI, Jap.Sin. 25, fol. 66 r. FR, II, 466.

$17 \quad F R$, II, 10, and 1onı.
} 
mandarin travelling to the imperial court, was the first attempt by Ricci to reach Beijing, a first attempt that was to prove sadly unsuccessful.

From these few records an outline of Pereira's life finally emerges. Manuel Pereira was born in Macao in $1575 .{ }^{18}$ Next to nothing is known about his childhood and youth, but it may be inferred from a few references, including the 1621 catalogue listing the members of the Society in the China mission, that he was educated by the Jesuit fathers at their earlier, more modest college of Madre de Deus in his native city, where he would have been taught reading and writing, as well as Latin. In that catalogue, he is described as a former student of the humanities in a table recording years of study and subjects. ${ }^{19}$ When still an eighteen-year old teenager he had apparently been sent to study painting in Japan between 1593 and 1598 - evidently as a promising student and possibly even a Jesuit candidate - where he learnt his craft at the school of the Italian Jesuit artist Giovanni Cola (156o-1626), also known as Giovanni Nicolao. ${ }^{20}$ This could have been at Arie, probably near today's Minami-shimabara city, where Nicolao's school had moved from Shiki in $1593 .{ }^{21}$

As may be concluded, by the first half of 1598 , young Manuel had already gone back to China (perhaps as a consequence of the Nagasaki martyrdom of Christians the year before) as a dōjuku 同宿, a Japanese term for a Buddhist novice adapted by the Jesuits to mean a Catholic attendant to the missionaries. When he travelled with Ricci on the aforementioned first trip to Beijing, he went with his fellow Macanese Sebastiano Fernandez; the young artist was therefore a twenty-three-year-old lay assistant to the Jesuit missionaries. Leaving the Portuguese fathers João da Rocha and João Soerio in the Jesuit residence in Nanchang, Ricci relates how "[t]hey left with Fr. Cattaneo and with Br. Bastiano, and with Br. Manuel Pereira who, however, had not yet been received into the Society."22 We find Manuel Pereira with Ricci on the trip back from Beijing in November 1598, with a stop in the city of Linqing in Shandong. ${ }^{23}$

18 See catalog in ARSI, Jap.Sin. 135, ff. 4-5.

19 ARSI, Jap.Sin. 134, f. $301^{\mathrm{v}}$.

20 McCall, "Early Jesuit Art IV," 49-50. Nicolao's art school was opened at the instigation of Alessandro Valignano, McCall, "Early Jesuit Art in the Far East I: The Pioneers," Artibus Asiae 4 (1930-32): 67, 130. Nicolao's biography and his school of painters in FR, II, 231n3; J. Ruiz-de-Medina, "Cola, Giovanni (João Nicolao)," in DHCJ 1:838-839. On the school of painters see Bailey, Art on the Jesuit Missions, 66-81 and the forthcoming book by Mia Mochizuki in the Series of Jesuit Studies (Leiden: Brill, 2014).

$21 \quad$ DHCJ 1:838.

$22 \quad F R$, II, 9-10. Persecution of Christians had begun in 1587 under Toyotomi Hideyoshi.

$23 \quad F R$, II, $54-55$. 
Another outstanding moment took place, once again, while a companion to Ricci. In 16oo, on the second and this time successful attempt to enter Beijing, Ricci decided that it was Cattaneo's turn to stay behind in Nanjing, taking with him the Spaniard Diego de Pantoja (1571-1618) instead, together with Sebastiano and young Manuel. ${ }^{24}$ Manuel Pereira was, therefore, part of the small group of Jesuits that finally made a historic entry into the Forbidden City and the imperial court with presents for the Wanli emperor (r. 1572-1619). ${ }^{25}$ But not all of the young assistant's experiences in the China mission were to be as splendid. Manuel also accompanied Ricci in arduous journeys that included persecution and several extremely harrowing clashes with local mandarins. The later painter of the Ricci portrait was, therefore, well acquainted with the trials, the features, and the character of his mentor.

From the 1598 text cited above, it is clear that Manuel Pereira remained a lay assistant during this period of his life, later becoming a postulant and, as may be gathered from the October 1603 catalogue, was finally admitted as a novice in 1603 after several years of service in the Nanjing residence, in all probability in August of that year. It was in Nanjing that he became a Jesuit temporal coadjutor, or brother, on August 15, 1605, that is, just less than five years before Ricci's death. The Jesuits attached a special importance to August 15, the feast of the Assumption of Mary. Moreover, in the Japan mission it was remembered as the day of the Francis Xavier's landing in 1549 in Kagoshima, Japan-not far from where Manuel had studied under Giovanni Nicolao. That he would become a temporal coadjutor on this feast day is therefore quite consistent with the known facts of his religious vocation. Besides, in this early phase of the history of the Jesuits' China mission, becoming a brother was the only option open to him, as East Asians were barred from entering the priesthood. But it is doubtful, given his artistic temperament, that he would have chosen the priesthood. ${ }^{26} \mathrm{He}$ was again described as a temporal coadjutor in 1617 , while living at the Jesuit residence in Guangdong province.

One of the most affecting passages in the Fonti Ricciane describing the tragic moments leading to Ricci's death states that the Italian missionary comforted Manuel by telling him that he would implore God to let him persevere in his

\footnotetext{
$24 \quad F R$, II, 100 and 10on6.

$25 \quad F R$, II, $568 \mathrm{n}_{5}$.

26 The first Chinese priest was only ordained in about 1663. See Francis A. Rouleau, S.J., "The First Chinese Priest of the Society of Jesus, Emmanuel de Siqueira, 1633-1673," AHSI 28 (1959): 16-20; Charles Ralph Boxer, The Church Militant and Iberian Expansion (1440-1770) (Baltimore: The John Hopkins University Press, 1978), 2, 23-26.
} 
vocation. ${ }^{27}$ Brother Manuel's name no longer appears in the catalogue of members of the Society for 1636 , but he was to remain faithful to Ricci's deathbed entreaty until the time of his own death in 1633 .

\section{Manuel Pereira's Artistic Production}

Apart from Ricci's portrait very little is known of Pereira's artistic production. A precious observation in the Fonti Ricciane - presumably by Ricci himselfrelates how in Nanjing, in 16oo, while on his second trip to Beijing with Matteo Ricci, Manuel Pereira was asked to paint a copy of a painting of the Virgin and Child with St. John the Baptist, which the Jesuit missionaries carried with them with other items as gifts for the Ming emperor. ${ }^{28}$ This copy was created after the wife of the mandarin Liu Dongxing 劉東星 had seen a similar painting in a dream; if this is not a fictitious tale, it must be one of the most remarkable instances of clairvoyance in missionary history. Realizing to her surprise that the Jesuits were in possession of such an image, she asked for it to be copied by her own artist. But the Jesuits proposed that Manuel make a copy instead; unlike a "pagan" Chinese painter, Manuel, as a Catholic, knew the deep religious significance attached to the subject and would be able to render it correctly.

Besides other imperial offices, Liu Dongxing, described in the Fonti Ricciane as the viceroy, was actually director general of grain transport in Shandong. ${ }^{29}$ The depiction of the Virgin and Child with St. John given to him at the request of his wife was actually a replica of a painting that had actually been brought from New Spain by way of Manila and sent as a gift for the Chinese emperor and was therefore a historic work of art in its own right. D'Elia believed it to be similar to the painting of the Virgin and Child with St. John and St.Joseph, found in the Jesuit residence at the Gesù, but this is rather doubtful. ${ }^{30}$ The latter has apparently been poorly restored at some stage, or is a derivative work from the school of Andrea del Sarto (1486-1530), an Italian Renaissance artist. The painting shipped from Mexico was more likely by a later Spanish master, as large numbers of devotional works of art were shipped from Spain to the colonies in the American viceroyalties. Until more concrete details emerge regarding this mysterious painting, any attribution can only be hypothetical.

\footnotetext{
$27 \quad F R$, II, 540, 540 3, 4.

$28 \quad F R$, II, 105, 105 $5,6$.

$29 \quad F R$, II, 103, 103n2.

$30 \quad F R, \mathrm{I}, 232 \mathrm{n} 1$.
} 
Apart from this copy, which is now lost, more significant for this article is the fact that Manuel Pereira was one of six young Jesuit disciples of Ricci who collaborated on the production of Ricci's Chinese map of the world, produced in Beijing in 1603 , to be discussed in more detail below. ${ }^{31}$

The Macanese artist is reported to have been in good health - the catalogue of the Jesuit Chinese vice-province lists him as "robust and in good health."32 In spite of these physical attributes, it appears that his more intellectual gifts, such as his inner qualities or gifts as a painter, did not meet with the same recognition from at least some of his confrères. A letter written soon after his death, dated November 1, 1633 by Manuel Dias the Younger, vice-provincial of the Chinese vice-province, confirms this impression, reporting that Manuel Pereira "died in 1633 after having been very useful to the mission, although he was a painter of common talent." 33 Such was the epitaph on the painter of the Ricci portrait, the disciple that Ricci had nurtured with care, as perhaps others had in the China and Japan missions. Whether fairly or unfairly, his talents as an artist tend to be dismissed by researchers today. ${ }^{34}$ But Dias's estimate still begs the question: what was the real merit of Pereira's portrait of Ricci? Before answering it, it is necessary to look at stylistic developments in portrait painting current at the time in both China and the West.

\section{Developments in Chinese Ming Portraiture}

During the late Ming period (1567-1644), a period that includes the time that Ricci and Pereira lived in the Middle Kingdom, partly informal portraits of scholars flourished at the hands of masters such as Zeng Jing 曾鯨 (1564-1647) and Chen Hongshou 陳洪綬 (1598-1652).35 Such portraits incorporated aspects of both the formal and the informal portrait, the two main categories of traditional portraiture in China. ${ }^{36}$

Artistic features derived from Western portraits in Manuel Pereira's representation of his mentor are perhaps more readily apparent. What has escaped

31 A painting of the Savior for Chala Cemetery chapel is sometimes attributed to Pereira, but this was by Giacomo Niva (FR II, 625-626).

32 Listed as no. 20, ARSI, Jap.Sin, 134, ff. 304, 306.

33 DHCJ 4:4060.

34 Bailey, Art on the Jesuit Missions, 96; McCall, "Early Jesuit Art IV," 51.

35 The Dictionary of Art, ed. Jane Turner (London: Macmillan, 1996), 4:812-13; James Cahill, The Compelling Image: Nature and Style in Seventeenth-Century Chinese Painting (Cambridge: Harvard University Press, 1982), 106-145.

36 Dictionary of Art, 4:811. 
the attention of previous researchers are those qualities it shares with Ming literati portrait painting. A perfect example is a masterly ink and color on silk Portrait of Shen Zhou 沈周 (1427-1509) (fig. 2).

This 1507 half-length frontal portrait of the renowned landscape painter shows one of the Four Great Masters of the Ming dynasty, with an inscription above his head describing the particularities of his features as an old man of eighty. Zhen Shou is the epitome of the Chinese literatus and although this portrait was painted almost one hundred years before that of Ricci, some of the similarities between them are remarkable. Particularly striking are the hard line of the curve of the black hat over the forehead, the intensity of the almost pentagonal shape of the two-dimensional hat - in this portrait the only black item of clothing - the wrinkles around the eyes, the protruding left ear, the height and actual shape of the tall collar that touches the left earlobe, and the beard falling over the collar. His portrait follows an already well-established traditional type and style, with a plain monochrome background to indicate space, where only calligraphic inscriptions and red square stamps are allowed to disrupt the surface of the painting. Eleventh-century full-length portraits already depicted similar tall black hats on portraits of venerable officials. The ink and color on silk paintings of Feng Ping 馮平像 and Wang Huan 王渙, today at the Freer Gallery of Art, Washington, DC, as well as that of Bi Shichang 畢世長, now in the collection of The Metropolitan Museum of Art, New York, show elderly gentlemen officials, with their images strongly silhouetted in black against plain backgrounds. Here the age of the person being portrayed is a central theme of the paintings because they form part of a set in a Northern Song middle-sized album that depicts the Five Elders of Suiyang 睢陽五老圖. ${ }^{37}$ There are other equally surprising examples that provide evidence that Pereira faithfully attempted to depict his Jesuit mentor as a literatus, that is, in the way in which Matteo Ricci saw himself during his missionary life in China.

\section{Ancestor Portraits}

Although Pereira's work reveals a close similarity with Chinese literati portraits, it is tempting to search for an even closer correspondence with Chinese ancestor portraits because of its posthumous nature. But comparing it to this genre of Chinese portraiture is valid mainly because it helps us to understand

37 <http://www.metmuseum.org/toah/works-of-art/17.170.1>. See also the Freer Gallery of Art project: $<$ http://www.asia.si.edu/SongYuan/F1948.11/F1948-11.Documentation.pdf >1, 7 . 


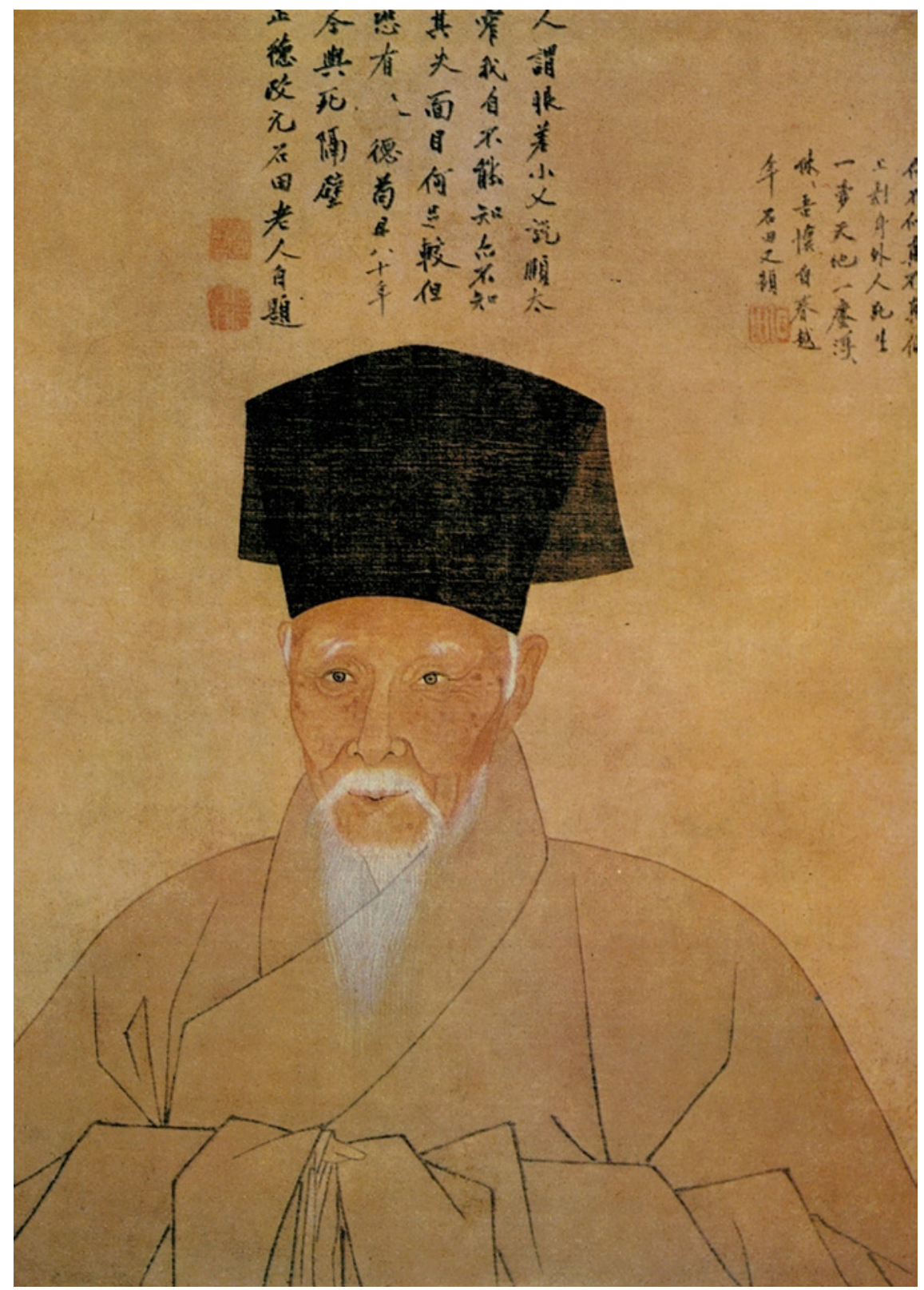

FIGURE 2 The 1507 Portrait of Shen Zhou 沈周 (1427-1509). Ink \& color on silk. Palace Museum, Beijing. 
more clearly what the portrait of Ricci is not. Ancestral portraits, which were produced from at least the second-half of the fifteenth century, attained greater importance after the late Ming dynasty, at the time that Ricci's portrait was created. Its most impressive examples include representations of revered Chan Buddhist teachers. ${ }^{38}$ Here even a greater similarity is arguable, namely between the icon of Ricci as a venerable Christian sage and these types of Buddhist portraits.

However, unlike Manuel Pereira's likeness of his teacher, all such Chinese ancestral portraits, religious or secular, served a purpose far more complex than that of perpetuating a likeness of the deceased for sentimental reasons. Central objects in the post-funerary rites that followed burial, rites that came to be called in the West ancestor worship (that is, ritual ceremonies expressive of filial piety for deceased relatives), these portraits, as befitted their function, represented the dead person almost life-size, enthroned in a round-backed seat of honor. ${ }^{39}$ The tradition had a distinguished pedigree in imperial ancestral rites, where sculptures and portraits played an intrinsic role. ${ }^{40}$ Full frontal poses were the norm and-unlike more typical Chinese portraits, especially those of literati-inscriptions of any kind, including descriptions that identified ancestors, were usually omitted and considered unnecessary since the sitter was already known to family members. ${ }^{41}$ During these post-funerary ceremonies the presiding images placed on altars were treated as objects of veneration, if not worship, by family and clan members. While it is not possible here to discuss in much detail the traditional Chinese practice of sacrifice to ancestors or the Rites Controversy, it is nonetheless important to recall that Ricci played a pivotal role in the interpretation that the Society of Jesus gave to ancestor rituals in China. With the exception of some of the more enlightened Jesuits, such as Ricci, these rituals were considered idolatrous by most Catholic and Protestant missionaries up until the nineteenth century. ${ }^{42}$ There is perhaps a certain irony in the fact that Ricci's own portrait in the Gesù in Rome would become an object of reverence for the Jesuits and the faithful.

38 Dictionary of Art, 4:811; Cahill, Compelling Image, 114.

39 Jan Stuart and Evelyn Sakakida Rawski, Worshiping the Ancestors: Chinese Commemorative Portraits (Palo Alto: Stanford, Freer Gallery, 2001) 53-55, 6o, passim.

40 Patricia Ebrey, "Portrait Sculptures in Imperial Ancestral Rites in Song China," T'oung Pao 83 (1997): 42-92.

41 Stuart and Rawski, Worshiping, 148.

42 James Thayer Addison, "Chinese Ancestor-Worship and Protestant Christianity," The Journal of Religion 5, no. 2 (Mar. 1925), 140-9. 
Representative forms of the more formal type of ancestral portraits were executed in watercolors on silk mounted on large hanging scrolls. What is perhaps most striking about these portraits are the rich pigments used to record the symbols and emblems as well as the complex patterns embroidered into the sitter's robe. These elaborate designs and rich colors had two main ritualistic and stylistic purposes. On the ceremonial level, they served to remind respectful worshippers of the deceased's rank. On the stylistic level, they were used by the painter to create a visual contrast between the fabrics and the face. Unlike the robes, throne chairs, and carpets, faces were painted in monochromatic flesh-colors. The whole was rendered in a two-dimensionality that stands in sharp contrast to the effects of rounded volume and depth that had so preoccupied European artists since the Renaissance. All that was required of the Chinese artist was to reproduce in linear form a faithful facial resemblance of the dead person. Moreover, as these were images of the dead, the absence of facial expressions, or at least of lively ones, was practically an obligatory requisite for painters of the genre. The eyes were made to appear to be looking at approaching worshippers, but the artist had to take care to depict the gaze of the dead ancestor as issuing from an afterlife, thus transmitting to the worshipper the fact that he or she now inhabited an unknown region that was not an earthly one. The painter strove to give to the eyes the impression that the sitter's spirit expanded outwards, something that was more important than depicting a human expression. ${ }^{43}$

\section{Contemporary European Influence}

Although perspective is practically absent from the Ricci portrait, when it comes to the two traditions of portraiture that influenced Pereira's work, it was a number of technical and stylistic features characteristic of contemporary European portraits - learnt at the studio of Giovanni Cola in Japan or elsewhere in the Jesuit missions - that would prove more useful to him for dramatic effects. There is the use of oils on canvas and of richer color harmonies. There is also the artistic fiction of a light source and of a three-dimensional head and body emerging from a flat canvas, as well as a landscape that, as in physical reality, provides spatial depth. Moreover, there is a preoccupation with the subtleties of facial expression that is quite different from those of the Chinese ancestral paintings discussed above. To make the spectator aware of it, he has imaginatively focused his attention on Ricci's face. The result has 
been a work that brings to mind the serious spiritual quality of early CounterReformation religious portraits and prints, such as El Greco's 1595 to 1600 Portrait of Antonio de Covarrubias — characteristically, a Humanist, lawyer, and Tridentine scholar-today in the Louvre Museum. ${ }^{4}$

The long pointed sharp rays radiating from the orb with the emblem of the Society of Jesus behind the image of Ricci could be read as the main source of light. The design of these spike-like rays did indeed serve as a symbolic representation of certain luminous physical or spiritual bodies at the time in the West, such as comets, halos of sacred images or pictures of the Virgin Mary. But if one looks closely at the chiaroscuro effects in the picture, it is evident that no light falls over the back of Ricci from the emblem. Instead there is a thick black outline that dramatically isolates Ricci's body from the surrounding sky. Rather than a source of light, the glowing emblem of the Society is an opaque selfcontained symbol floating in the middle distance. It cannot be read as a physical or spiritual luminary: the real source of light lies somewhere outside the picture frame that bathes the face and sleeves of the robe with light from the front. Apart from creating a more realistic rounded image, this outer light seems to have been exploited by the painter to create an artistic effect expressive of another kind of radiance. One has to turn to Ricci himself and his ideas on the cosmos to find answers as to what that other dimension was.

\section{The Physical and Spiritual Realms}

As the Jesuit historian Henri Bernard has pointed out, although Ricci remained modest about his scientific knowledge, he was nonetheless aware that it was well ahead of much of what he was encountering in Ming China. This was because Chinese science had stagnated after the splendors attained during the Yuan Dynasty. ${ }^{45}$ Ricci's claim, therefore, that in China he had acquired fame as the greatest mathematician on earth may not be too farfetched. Moreover, he was also thought of as another Ptolemy, something he repeats several times in his journal. ${ }^{46}$

44 David Davies and J.H. Elliott, eds., El Greco (London: National Gallery, 2003), 276-279.

45 Henri Bernard, S.J., Matteo Ricci's Scientific Contribution to China, trans. E. C. Werner (Beijing: Henri Vetch, 1935), 14, 48-40. See also A. Chapman, "Tycho Brahe in China: The Jesuit Mission to Peking and the Iconography of the European Instrument-Making Process," Annals of Science 41 (1984): 417-433.

$46 \quad F R$, I, NN. 266, 212n8. An account of Ricci's contribution to scientific knowledge in China in $F R$, II, [538]. 
Cosmography is of particular interest here because it can disclose an important aspect of Pereira's portrait that can be easily overlooked. But as important as Ricci's claims in this respect were, as a cosmographer Ricci was mainly following the acquired wisdom of the Italian Renaissance, included in the plan of studies at the Collegio Romano, his university in Rome. It was based on the concept of the universe elaborated by the ancient mathematician and astronomer Ptolemy of Alexandria (c.90-168 CE), in a book today usually known by its Arabic name, the Almagest. ${ }^{47}$

Ptolemy's writings remained equally influential for the geographers of the age, but their maps had been supplemented by the geographical discoveries of Spanish and Portuguese explorers. Among the most outstanding cosmographies of the sixteenth century were the productions of the German mathematician and astronomer Peter Apian (1495-1552), and that of the Portuguese cartographer Bartolomeu Velho (d.1568). Apians's Cosmographia was published in 1524 and 1533 (fig. 3), while the map of the universe by Velho appeared in 1568 .

In spite of a lapse of some four decades between the first publication of Peter Apian's popular book and that of Bartolomeu, the depiction of the celestial bodies found in the latter is only a more colorful rendering of a similar image in Apian, which in turn derives from De sphaera, the 1220 book by the English Augustinian monk Johannes de Sacrobosco. The works of both these cosmographers bear witness to the fact that, with a few alterations, the Ptolemaic system had gained a strong hold on the European scientific imagination by the time Ricci entered the Collegio Romano. ${ }^{48}$

Ricci's studies ran from 1572 to 1577 and included mathematics, philosophy, and theology. ${ }^{49}$ He acquired much of his mathematical learning through his teacher Cristopher Clavius, the German scholar who had written a famous commentary on Sacrobosco. ${ }^{50}$ It was therefore the Ptolemaic vision of the universe that Ricci was to pass on to his Chinese students in the Middle Kingdom. More than half a year after his death, his scientific teaching continued among

\footnotetext{
47 See Bernard, Matteo Ricci's Scientific Contribution to China, 26-7, 30.

48 Ibid., 24.

$49 F R$, II, 555-557 gives an account of Ricci's studies at the Collegio. See also Bernard, Matteo Ricci's Scientific Contribution, 23; Gianni Criveller, "The Background of Matteo Ricci: The Shaping of His Intellectual and Scientific Endowment," in Portrait of a Jesuit: Matteo Ricci (Macau: Macau Ricci Institute, 2010), 20, 23-33.

5o Bernard, Matteo Ricci's Scientific Contribution, 33-6, passim. For a brief assessment of Clavius's contribution to scientific thought see David C. Lindberg and Ronald L. Numbers, eds., God and Nature: Historical Essays on the Encounter between Christianity and Science (Berkeley: University of California Press, 1986), 93-5.
} 


\section{LIBRI COSMO.}

Fo.V.

Schema huius præmiffx diuifionis

Sphararum.

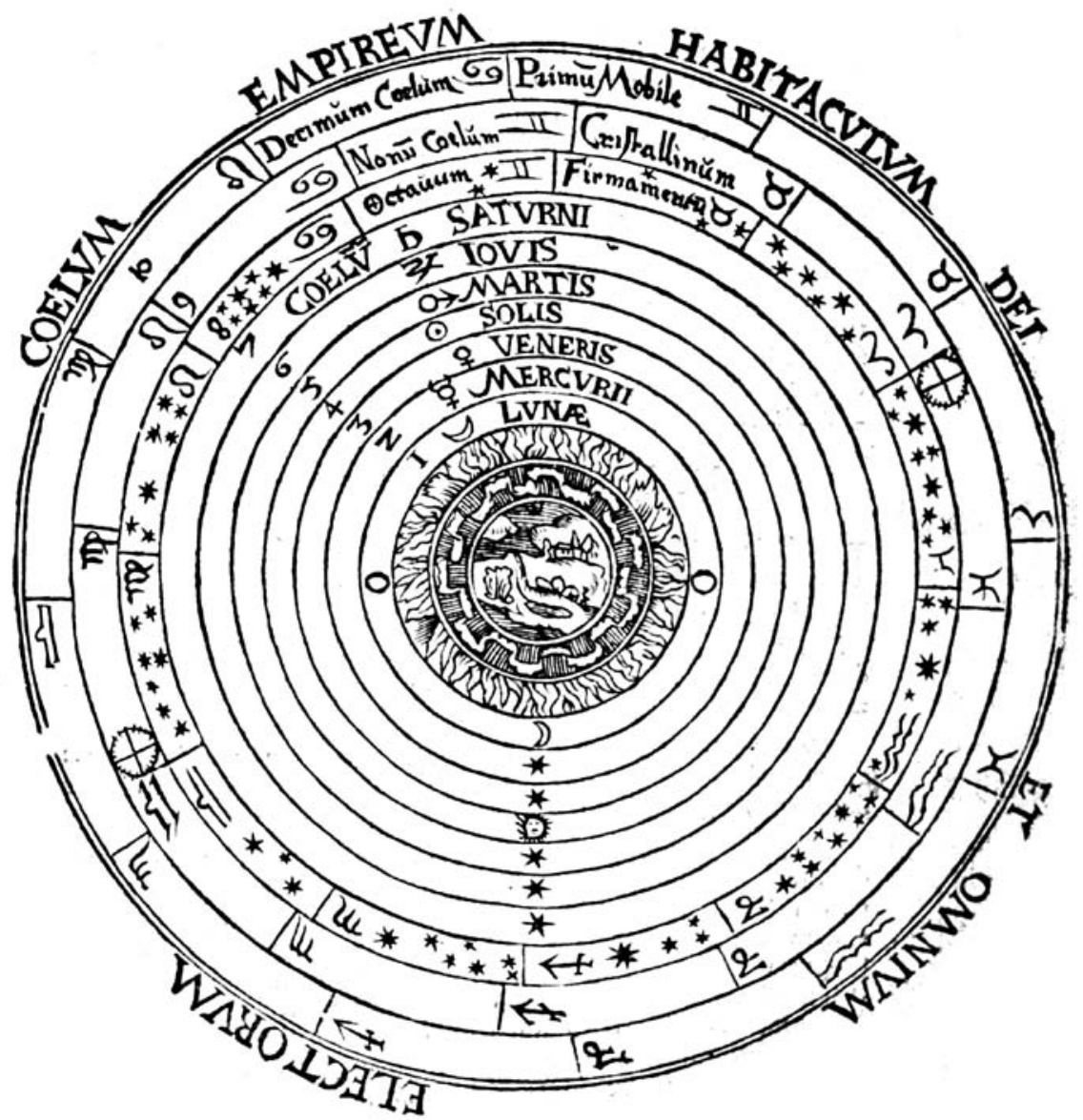

B

FIGURE 3 Petrus Apianus, Cosmographia, 1540 edition (Courtesy of History of Science Collections, University of Oklahoma Libraries). 
his confrères and disciples, ${ }^{51}$ and it can be reasonably concluded that Pereira, as one of his favorite disciples, had imbibed at least some of his cosmographical ideas and that these are reflected in the portrait. Evidence that Pereira was involved with these concepts is provided by Ricci's map of the world.

D'Elia, in a ground-breaking study on the subject, carefully considered the Chinese editions of Ricci's world maps. The heavenly and terrestrial charts printed on its corners to illustrate what are called "General Notions of Cosmography and Geography" are already found in the magnificent eightpanel edition produced in Beijing in $1603 .{ }^{52}$ Some of the Chinese versions of the map display profuse inscriptions in Chinese characters, comprising traditional laudatory prefaces by various literati. After eulogizing Ricci and his first six Chinese Jesuit disciples for their chastity, in his preface to the 1603 Bejing edition the scholar Paul Li Ying-shih 李应试 clearly states that together with five others-which include the Chinese-Japanese painter Giacomo Niva or Niwa (1579-1635) and Pereira's fellow Fernandez, mentioned earlier-Pereira had also participated in the production of this particular edition. ${ }^{53}$ The main cosmographical chart here, which is located at the top righthand corner of the first panel, illustrates the concentric circles of the various heavens. Here in this still Ptolemaic universe there appears the immutable and very Catholic eleventh heaven, where the throne of the Lord of Heaven, the saints, and the angels resided in a wonderful state of bliss, "eternally silent and immovable." 54

Thoroughly unlike the stars and seven planets that inhabited the concentric rings of the geocentric universe-and distinguished absolutely from themthere lay the Empyrean Heaven. The concept of the Prime Mover and of the Empyrean Heaven beyond it, where God and the Saved had their dwelling, were a major addition of Scholastic theology to the Ptolemaic system. To learn about this timeless abode the scientific studies taught at the Collegio Romano were not considered sufficient or adequate and gave way to the higher discourse of theology. If the sixteenth-century understanding of the universe may appear odd today, the theological concept of Heaven taught by the Jesuits may seem equally fanciful. This imaginary realm was also made up of circles,

\footnotetext{
51 Bernard, Matteo Ricci's Scientific Contribution, 74.

$5^{2}$ These charts could already have been present in the original Chinese map produced in Nanjing in 16oo. See Pasquale M. D’Elia, S.J., "Recent Discoveries and New Studies (19381960) on the World Map in Chinese of Father Matteo Ricci SJ," Monumenta Serica 20 (1961): 89, 94-95, 123, 145-146, and 146n184, Plate I.

53 Ibid., 146.

54 Ibid., 126, Plate III.
} 
although they were populated by legions of angels and seraphim, with the abode of God and the Saved as the highest, most perfect, and ultimate region. The old theories of the universe may have been refuted, but perhaps it is precisely in the discourse regarding the existence of a non-physical "immovable" dimension extending beyond matter and physical decay - as reflected in the portrait of Ricci - that the intuitions of Jesuit and Christian philosophers and theologians of the age may present the greatest challenge to Positivism today. It certainly allows us to perceive more clearly what Pereira's intention was in his depiction of the light source of his painting and the expression of Ricci's eyes. In the painting, as the light of the world dims, the light of this other universe emerges.

\section{Light from a Non-physical Universe}

At the time that Pereira produced his work, the style of the early Baroque was coming into its own in Rome. In this new style, dramatic poses, flowing robes, and heads lifted skyward were becoming the fashion. But in Pereira's work, which still harks back to the spirit of the early Counter-Reformation, the body and head of Ricci appear virtually motionless. As discussed, his head is set against a dark blue sky. Here the pose and the direction of the eyes are closer to the portraits of Chinese literati, but they also to some degree recall paintings and prints of Christian saints. Only his eyebrows are raised, while his eyes turn slightly towards a vision that appears to lie outside the picture plane. As a radiance illuminates it, the artist has given Ricci's face a subtle expression of awe and inner joy with the minimum of means.

At the moment of Ricci's death, with Pereira present, the Jesuit missionaries had tried to restrain mourners from exaggerated displays of grief. They pointed out to them that the transit of the blessed was different from those of mere mortals, and that they were certain Ricci had already joined the glory of the blessed. ${ }^{55}$ It is this spiritual state that Pereira tries to convey to the viewer of the portrait. In Pereira's conception Ricci is not shown in a realm inhabited by the spirits of the dead, as he would be in an ancestral portrait. He is rather in a state of bliss, as his eyes contemplate an otherworldly universe that only he can see and that could only be the Empyrean. It is indeed mainly through the expression of the eyes that we realize that the portrait represents Ricci's beatific vision. 


\section{Manuel Pereira's Significance for Chinese Painting}

Pereira's portrait of Ricci also occupies a small niche in the history of Chinese portrait painting. The artist's adoption of some characteristic features of European painting distinguishes it as one of the pioneering works that introduced Western artistic concepts to China. European novelties in prints and oils had already been noted by a small number of Chinese painters, soon after Jesuit missionaries, in the spirit of the Council of Trent, began to make use of religious images. Some researchers today believe the influence of Western painting may have appeared as early as the 1580 s, in the works of the painter of landscapes and religious Buddhist figures Ding Yunpeng 丁云鵬 (1547-1621). It is thought that in creating one of his depictions of Guanyin, he may have adapted the images of the Virgin and Child that Ricci brought as gifts on his missionary journeys in China. ${ }^{56}$

As regards portraiture, some critics also consider the three-dimensionality of Western oil painting to have been assimilated by the early seventeenthcentury portraitist Zeng Jing 曾鯨 (c.1564-1647). A native of Fujian province, Zeng had travelled to Nanjing, Hangzhou, Ningbo, and other places as a professional portrait painter and may well have come into contact with European pictures in Fujian and Nanjing. ${ }^{57}$ Although his hanging scrolls and hand scrolls show his sitters in a neutral empty space that is one of the main characteristics of his style, he also became known for the verisimilitude of his portraits and the facial expressions of his sitters, both indicative of Western influences. It has even been argued that because Pereira was in Nanjing in 1613 and four years later in Hangzhou, the influence of his portrait of Ricci may be discerned in Zeng Jing's Portrait of Zhao Shi'e 趙士鍔. 58 These European influences could have survived in the Bochen School 波臣, formed by the followers of Zeng Jing, and through them in the work of Qing portrait painters with their emphasis on individual facial expressions.

Thus, while for some of the Jesuits in the China mission You Wenhui, alias Manuel Pereira, was ranked as a rather limited artist (something there is no way of verifying, as only one of his paintings has come down to us), at least this painting, which is a wonderful offshoot of Counter-Reformation religious

56 Yang Xin, "The Ming Dynasty (1368-1644)," in Three Thousand Years of Chinese Painting, eds. Richard M. Barnhart, et al. (New Haven: Yale University Press, 2002), 236.

57 Xin, "Ming Dynasty," 243; Cahill, Compelling Image, 116-117.

58 莫小也 Mo Xiaoye, 十七一一十八世紀傳教士與西畫東漸 Shiqi-shiba shiji chuanjiaoshiyu Xi-hua dongjian [Missionaries and the Transition of Western Painting to the East in the 17th-18th Centuries] (Hangzhou: China Academy of Art Press, 2002), 93-4. 
portraiture, shows that the young artist was not entirely devoid of talent. This may be clearly seen in his ingenuity in blending artistic features of East and West to create a work in which his beloved master is not glorified as a great scientist, but rather as one who, after having brought the Gospel to China, was now enjoying another kind of glory. 